\title{
Sensitivity of cotton cultivars to soil compaction
}

\section{Sensibilidade de cultivares de algodoeiro à compactação do solo}

\author{
Jorge Falkoski Filho ${ }^{1}$; Itaynara Batista ${ }^{1}$; Ciro Antonio Rosolem ${ }^{2 *}$
}

\begin{abstract}
Cotton is one of the most sensitive crops to soil compaction, but there may be genetic variability for this trait. The objective of this study was to evaluate cotton cultivars sensitivity to soil compaction. Soil columns were built with three pvc rings with internal diameter of $10 \mathrm{~cm}$ and filled with an alfisol. The heights of the top and bottom rings were $15 \mathrm{~cm}$, and the intermediate ring, in which the soil was compacted, was $3.5 \mathrm{~cm}$ high. The levels of compression used in the subsurface were characterized by penetration resistances of $0.41,0.93,1.41$ and $1.92 \mathrm{MPa}$. The cultivars 701 FMT, FMT 705, FMT 707, FMX 951 LL and FMX 966 LL were grown up to 23 days after plant emergence, when the dry matter of shoots and roots, root length density and root diameter were determined. The cotton cultivars have variability in their sensitivity to resistance to penetration. The cultivar 707 FMT is more sensitive to soil compaction, while the FMT 701 is more tolerant. Penetration resistance of around 0.92 to $1.06 \mathrm{MPa}$ reduce $50 \%$ cotton root growth, but resistance to penetration of $1.92 \mathrm{MPa}$ did not totally prevent growth. Key words: Gossypium hirsutum, penetration resistance, root growth, $\mathrm{Q}_{1 / 2}$ index
\end{abstract}

\section{Resumo}

O algodoeiro é uma das culturas mais sensíveis à compactação do solo, podendo haver variabilidade genética quanto a essa característica. O objetivo deste trabalho foi avaliar a sensibilidade de cultivares de algodão à compactação do solo. Utilizou-se um Nitossolo Vermelho distroférrico de textura argilosa, em colunas de solo montadas com três anéis de pvc sobrepostos, com diâmetro interno de $10 \mathrm{~cm}$. As alturas do anel superior e inferior foi de $15 \mathrm{~cm}$, e do anel intermediário, em que foi realizada a compactação, de $3,5 \mathrm{~cm}$. Os níveis de compactação utilizados em subsuperfície foram caracterizados pelas resistências à penetração de 0,$41 ; 0,93 ; 1,41$ e 1,92 MPa. As cultivares utilizadas foram FMT 701, FMT 705, FMT 707, FMX 966 LL e FMX 951 LL. Aos 23 dias após a emergência das plantas, determinaram-se as massas da matéria seca da parte aérea e das raízes, a densidade do comprimento radicular e o diâmetro médio radicular. As cultivares de algodão apresentam variabilidade quanto à sensibilidade à resistência do solo à penetração. A cultivar FMT 707 é mais sensível à compactação do solo, enquanto a FMT 701 é mais tolerante. Resistências à penetração da ordem de 0,92 a 1,06 MPa reduzem a $50 \%$ o crescimento radicular do algodoeiro, mas resistência do solo à penetração de 1,92 MPa não impede totalmente o crescimento.

Palavras-chave: Gossypium hirsutum, resistência à penetração, crescimento radicular, índice $\mathrm{Q}_{1 / 2}$

\footnotetext{
${ }^{1}$ Eng $^{{ }^{\circ}}$ Agr $^{{ }^{\circ}}$ do curso de Pós-Graduação em Agricultura, Faculdade de Ciências Agronômicas, Universidade Estadual Paulista, FCA/UNESP, Botucatu, SP, Brasil. E-mail: jfalkoskifilho@yahoo.com.br; itaynara@fca.unesp.br

2 Prof. Titular do Dept ${ }^{\circ}$ de Agricultura e Melhoramento Vegetal, FCA/UNESP, Botucatu, SP, Brasil. E-mail: rosolem@fca.unesp. br

* Author for correspondence
} 


\section{Introduction}

The total amount of compacted soil worldwide is approximately 68 million hectares and is therefore, a global concern (SOANE; VAN OUWERKERK, 1994). Adverse effects of compression include increased soil bulk density, reduction in porosity, restriction in suitable crop root development, and decreased productivity (HAMZA; ANDERSON, 2005). Because of root growth restriction, morphological changes occur, such as an increase in root diameter and twisted root formation (SILVA; ROSOLEM, 2002), which are specific for each species or cultivar (MATERECHERA et al., 1992). Studies have been performed on the effect of compression on various crops such as soybeans, corn, and wheat (FREDERICK et al., 1998; BUSSCHER; FREDERICK; BAUER, 2000). On the other hand, cotton was found to be more sensitive to soil compaction than that by soybeans, corn, and Brachiaria brizantha (SILVA; MAIA; BIANCHINI, 2006).

A penetration resistance of $2.0 \mathrm{MPa}$ is considered critical to the growth of most crop plants (TAYLOR; GARDNER, 1963), although it has been reported that cotton root growth can occur up to a penetration resistance of $2.45 \mathrm{MPa}$ (ROSOLEM et al., 1998). Cotton roots have been found beneath a layer with a $3.0 \mathrm{MPa}$ resistance (COELHO; MATEOS; VILLALOBOS, 2000). It has been postulated that there may be differences among cultivars, in which one genotype may have its root growth impeded with a penetration resistance of $0.59 \mathrm{MPa}$, whereas another may be impaired only at a resistance of 2.45 MPa (KASPERBAUER; BUSSCHER, 1991; ROSOLEM et al., 1998).

Thus, knowledge of varietal differences in the sensitivity to penetration resistance can provide insights into breeding programs, as well as assist in the selection of cultivars that are best suited to specific environmental situations. Thus, the aim of this study was to evaluate the sensitivity of cotton cultivars to soil compaction.

\section{Materials and Methods}

The trial was conducted in a greenhouse at UNESP, Botucatu, SP. The soil material was collected in the surface layer (0-20 cm) of a dystrophic Red Nitosol (EMBRAPA, 1999), which was sieved through a 4-mm mesh. The chemical analysis of the material based on the recommendations of Raij and Quaggio (1983) showed a $\mathrm{pH}$ of 4.1 in $\mathrm{CaCl}_{2} ; 13 \mathrm{mg} \cdot \mathrm{dm}^{-3}$ of $\mathrm{P} ; 0.3,11.0$, and $4.5 \mathrm{mmol}_{\mathrm{c}} \cdot \mathrm{dm}^{-3}$ of $\mathrm{K}, \mathrm{Ca}$, and $\mathrm{Mg}$, respectively; and a base saturation of $16 \%$. The maximum of soil water retention capacity, assessed in a tension table at $30 \mathrm{kPa}$ (COUTO; SANS, 2002), was $400 \mathrm{~g} \mathrm{~kg}^{-1}$. Lime was applied to correct the base saturation to $60 \%\left(280 \mathrm{~g} \cdot \mathrm{kg}^{-1}\right.$ of $\mathrm{CaO}$ and 200 $\mathrm{g} \cdot \mathrm{kg}^{-1}$ of $\mathrm{MgO}$ ) with $\mathrm{RNV} 95 \%$. After liming, the soil was moistened to $-30 \mathrm{kPa}$ and placed under plastic sheeting for 30 days. After this period, $120 \mathrm{mg} \mathrm{dm}^{-3}$ of $\mathrm{N}$ (urea), $150 \mathrm{mg} \mathrm{dm}^{-3}$ of P (triple superphosphate), and $150 \mathrm{mg} \mathrm{dm}^{-3}$ of $\mathrm{K}$ (potassium chloride) were added.

Columns were constructed using 3 superposed $\mathrm{PVC}$ rings having an internal diameter of $10 \mathrm{~cm}$. The height of both the upper and lower rings was $15 \mathrm{~cm}$, whereas that of the intermediate ring, in which the compression occurred, was $3.5 \mathrm{~cm}$ (ROSOLEM et al., 1998; ROSOLEM; FOLONI; TIRITAN, 2002), to simulate "grid walk," a common phenomenon in areas with conventional cultivation. The rings were attached using tape. Plastic tapes of about 2-in width were laid and folded from the periphery to the center of the upper surface of the compacted layer to prevent the growth of roots between the inner wall of the intermediate ring and the soil (MÜLLER; CECCON; ROSOLEM, 2001).

To obtain the desired values of penetration resistance, the calculated amounts of soil materials with known volume were added to the ring, so that after compaction, density values of $1.2,1.4,1.5$, and 1.6 $\mathrm{Mg} \mathrm{m}^{-3}$ were attained, with a moisture content of $80 \%$ of the field capacity. Next, resistance to penetration was determined according to Calonego and Rosolem (2011) by using a bench penetrometer 
(Marconi Model MA 933) with a 4-mm diameter shank and 6-mm diameter conical tip, a semi-angle of $30^{\circ}$, and a base area of $0.126 \mathrm{~cm}^{2}$. The speed of vertical displacement of the shaft was $1.0 \mathrm{~cm} \cdot \mathrm{min}^{-1}$, to a depth of $4.0 \mathrm{~cm}$ to ensure that a layer of 3.5 $\mathrm{cm}$ had been crossed. The soils of the vessel above and below the compacted layer had their density adjusted to $1.2 \mathrm{Mg} \mathrm{m}^{-3}$, similar to the natural state of the soil.

The total mass of pots with a humidity of $80 \%$ of field capacity was determined and was maintained throughout the experiment by daily weighing and by replacing the water through surface application.

The cotton cultivars FMT 701, FMT 705, FMT 707, FMX 966 LL, and FMX 951 LL were sown with pre-germinated seeds and grown for 23 days. The shoots were cut and dried in an oven at $60{ }^{\circ} \mathrm{C}$ for $48 \mathrm{~h}$ and weighed. The roots were divided into 3 portions, corresponding to the upper, compacted, and bottom layers of the vessels. They were then cleaned under running water, sieved using a $0.5-\mathrm{mm}$ mesh, and stored under refrigeration $\left(5 \pm 1^{\circ} \mathrm{C}\right)$ in a solution containing $0.30 \mathrm{~m}^{3}$ of ethanol per $\mathrm{m}^{3}$ of water. Images of the roots were scanned at $300 \mathrm{dpi}$ resolution and analyzed using the program "Win Mac Rhizo," version 3.8 (Regent Instrument Inc., Quebec, Canada), and the root length density and root diameter were evaluated. The $\mathrm{Q}_{1 / 2}$ index was determined using the adjusted model for root length density of the compacted layer (DEXTER, 1987). This index is the value of mechanical soil resistance to penetration in which the root growth is reduced by $50 \%$. After analysis, the roots were placed in paper bags, which were then placed in a forced air oven at $60^{\circ} \mathrm{C}$ for $48 \mathrm{~h}$, and then weighed.
The design of the experiment was completely randomized with 4 replications in a $5^{\prime} 4$ factorial scheme. Five cotton cultivars and 4 values of penetration resistance were evaluated. Data were subjected to regression analysis, and the equations that showed the highest coefficient of determination $\left(\mathrm{R}^{2}\right)$ were considered significant to $5 \%$ by the $\mathrm{F}$ test. The means were compared using the $t$ test (LSD) at $5 \%$.

\section{Results}

The values of soil penetration resistance (PR) in the compacted layer, obtained at densities of 1.2, 1.4, 1.5 , and $1.6 \mathrm{Mg} \mathrm{m}^{-3}$, corresponded to values of 0.48 , $0.93,1.41$, and $1.92 \mathrm{MPa}$, respectively. The shoot growth of cultivar FMT 701 responded positively to subsurface compaction of the soil, whereas the FMT 707 cultivar responded negatively. The FMT 705 and FMX 966 LL cultivars showed a quadratic response, with the minimum and maximum growth of the order of 1.25 and $1.15 \mathrm{MPa}$, respectively, whereas the growth in the FMX 951 LL cultivar was not affected. With the lowest compression value, cultivars FMT 707 and FMT 705 showed the highest dry matter yield of shoots (Figure 1A). The production of root dry matter by cultivars FMT 701, FMT 707, FMX 966 LL, and FMX 951 LL was hampered by the subsurface compaction with an increase in penetration resistance of 0.48 to 1.92 $\mathrm{MPa}$, whereas the FMT 705 cultivar presented an increase in root dry matter in the same range (Figure 1B). 
Figure 1. Dry matter of shoot [A (FMT $701 \mathrm{y}=0,47+0,24 \mathrm{x} \mathrm{R}^{2}=0,80^{*}$; FMT $705 \mathrm{y}=1,42-1,53 \mathrm{x}+0,62 \mathrm{x}^{2} \mathrm{R}^{2}=0,75^{* *}$; FMT $707 \mathrm{y}=1,08-0,26 \mathrm{x} \mathrm{R}^{2}=0,95^{*}$; FMX $966 \mathrm{LL} \mathrm{y}=0,07+1,27 \mathrm{x}-0,58 \mathrm{x}^{2} \mathrm{R}^{2}=0,97 *$; FMX $\left.\left.951 \mathrm{LL} \mathrm{y}=0,68 \mathrm{~ns}\right)\right]$ and dry matter full root [B (FMT $701 \mathrm{y}=0,29-0,07 \mathrm{x} \mathrm{R}^{2}=0,738^{* *}$; FMT $705 \mathrm{y}=0,18+0,06 \mathrm{x} \mathrm{R}^{2}=0,53 * *$; FMT $707 \mathrm{y}=0,32$ $-0,24 x+0,08 x^{2} R^{2}=0,79 *$; FMT 966 LL $y=0,64-0,61 x+0,19 x^{2} R^{2}=0,98 * * ;$ FMX 951 LL $y=0,27+0,24 x-0,16 x^{2}$ $\left.\left.\mathrm{R}^{2}=0,58^{* *}\right)\right]$ of cotton cultivars, depending on the resistance to penetration in the compacted layer. ** and * significant at 1 and $5 \%$ respectively. ns: not significant.
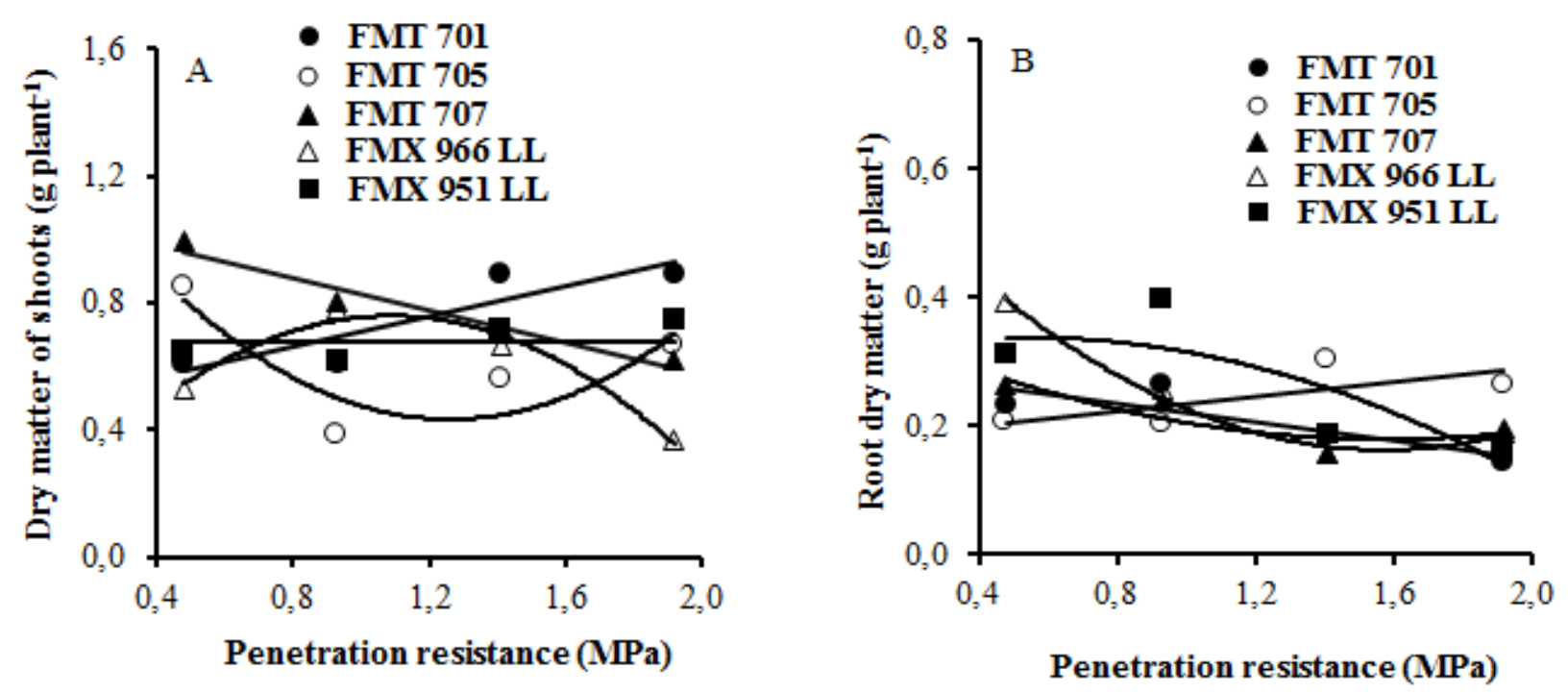

Source: Elaboration of the authors.

The response of root length density varied in the surface layer of the columns, in which the soil was not compacted, and thus, showed no signs of establishment of a pattern (Figure 2A). Thus, the observed changes would not have probably resulted in any agronomic significance.

The root length density was generally short in the compacted layer and all the cultivars presented a decrease in the density of root length with the increase in penetration resistance. Decreasing second-degree quadratic equations were most suitable to the results (Figure 2B), with minimal growth in penetration resistance of the order of 1.8 MPa. The calculation of $Q_{1 / 2}$ (DEXTER, 1987) or PR in which the root growth is reduced by half, revealed values of 1.06, 0.92, 0.95, 0.93, and $0.95 \mathrm{MPa}$ for the cultivars FMT 701, FMT 705, FMT 707, FMX
966 LL, and FMX 951 LL, respectively. Therefore, only the cultivar FMT 701 was less sensitive to soil compaction compared to the other cultivars. In the bottom layer, even without compression, fewer roots were found, and root growth was affected by compaction in the middle layer (Figure 2C).

The root diameter did not present changes that could apparently affect the agronomic behavior of cultivars, although some significant results were found in the ANOVA (Figure 3A). In the compacted layer, a trend of root thickening in the higher compressions was observed, except for cultivar FMX 966 LL (Figure 3B). In the lower layer (Figure 3C), cultivar FMX 951 LL showed an increase in root diameter when penetration resistance changed from the lowest to the highest value. 
Figure 2. Root length density of cotton cultivars, in the upper layer [A (FMT 701 $y=0,68+0,68 x-0,30 x^{2} R^{2}=0,98 * *$; FMT $705 \mathrm{y}=0,74+0,61 \mathrm{x}-0,29 \mathrm{x}^{2} \mathrm{R}^{2}=0,64 * *$; FMT $707 \mathrm{y}=1,14-0,14 \mathrm{x} \mathrm{R}^{2}=0,58 * * ;$ FMX 966 LL $\mathrm{y}=1,38-0,88 \mathrm{x}$ $+0,39 \mathrm{x}^{2} \mathrm{R}^{2}=0,95^{* *}$; FMX $\left.\left.951 \mathrm{LL} \mathrm{y}=1,15-0,14 \mathrm{x} \mathrm{R}^{2}=0,68 * *\right)\right]$, compacted [B (FMT 701 y=1,09-0,91x+0,20x $\mathrm{R}^{2}=0,99 * *$; FMT $705 \mathrm{y}=1,23-1,31 \mathrm{x}+0,37 \mathrm{x}^{2} \mathrm{R}^{2}=0,99 * *$; FMT $707 \mathrm{y}=1,11-1,11 \mathrm{x}+0,29 \mathrm{x}^{2} \mathrm{R}^{2}=0,99 * *$; FMX 966 $\left.\left.\mathrm{LL} \mathrm{y}=1,20-1,24 \mathrm{x}+0,33 \mathrm{x}^{2} \mathrm{R}^{2}=0,99 * * ; \mathrm{FMX} 951 \mathrm{LL} \mathrm{y}=1,09-1,12 \mathrm{x}+0,317 \mathrm{x}^{2} \mathrm{R}^{2}=0,99 * *\right)\right]$ and lower $[\mathrm{C}(\mathrm{FMT} 701$ $\mathrm{y}=0,18-0,08 \mathrm{x} \mathrm{R}^{2}=0,96 * * ;$ FMT $705 \mathrm{y}=0,21-0,10 \mathrm{x} \mathrm{R}^{2}=0,96 * * ; \mathrm{FMT} 707 \mathrm{y}=0,86-1,12 \mathrm{x}+0,36 \mathrm{x}^{2} \mathrm{R}^{2}=0,99 * * ; \mathrm{FMX}^{*}$ $966 \mathrm{LL} y=0,77-0,89 \mathrm{x}+0,26 \mathrm{x}^{2} \mathrm{R}^{2}=0,98 * *$; FMX $\left.\left.951 \mathrm{LL} \mathrm{y}=0,41-0,41 \mathrm{x}+0,11 \mathrm{x}^{2} \mathrm{R}^{2}=0,99 * *\right)\right]$ depending on the resistance to penetration in the compacted layer. $* * 1 \%$ significant.
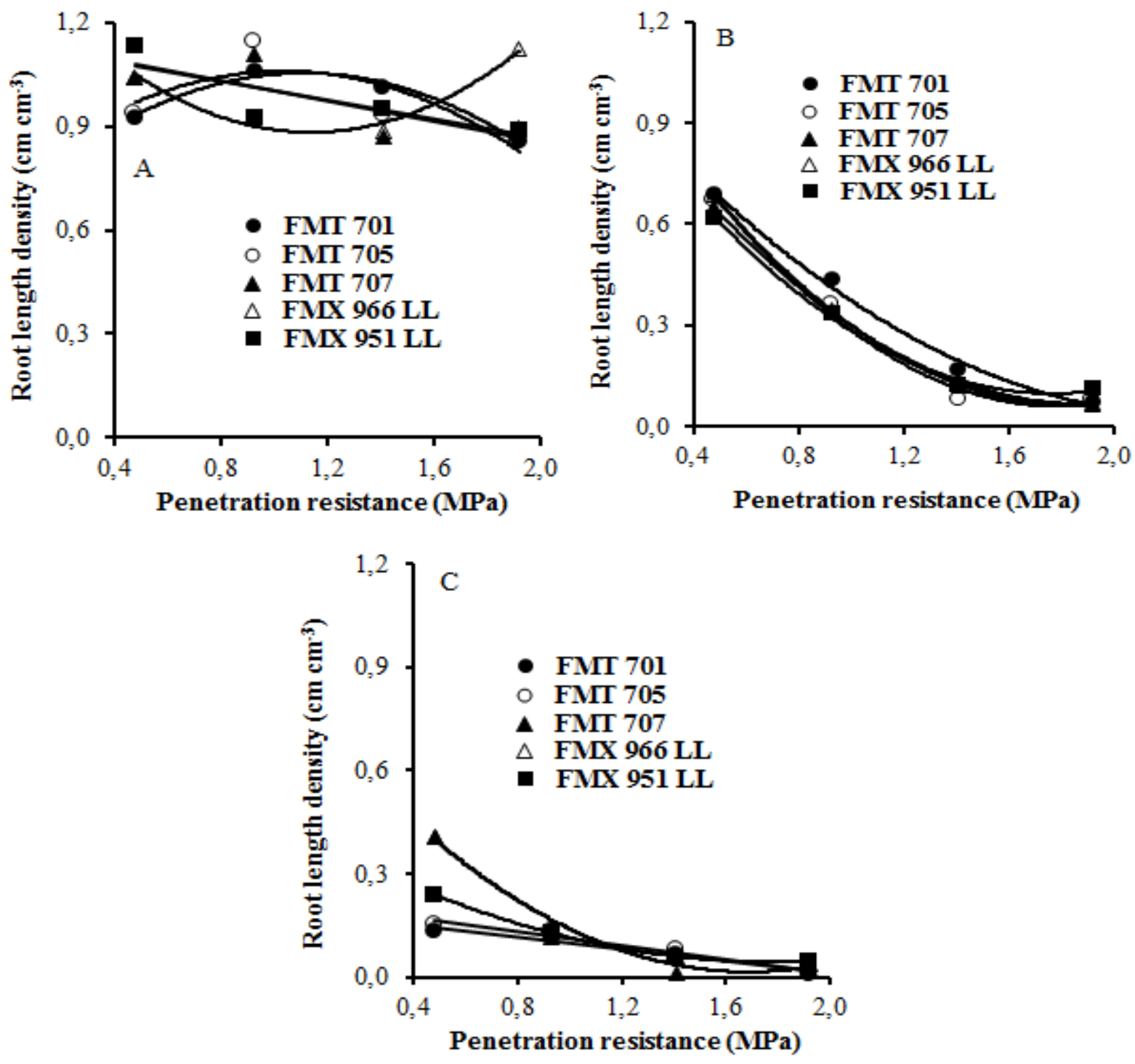

Source: Elaboration of the authors. 
Figure 3. Root diameter of cotton cultivars, in the upper layer [A (FMT $701 \mathrm{y}=0,05 \mathrm{~ns}$; FMT $705 \mathrm{y}=0,30-0,36 \mathrm{x}+$ $0,13 x^{2} R^{2}=0,89^{* *}$; FMT $707 \mathrm{y}=0,27-32 \mathrm{x}+0,12 \mathrm{x}^{2} \mathrm{R}^{2}=0,76^{* *}$; FMX 966 LL $\mathrm{y}=-0,26+0,46 \mathrm{x}-0,17 \mathrm{x}^{2} \mathrm{R}^{2}=0,81^{*}$; FMX $\left.951 \mathrm{LL} y=0,30-0,37 \mathrm{x}+0,13 \mathrm{x}^{2} \mathrm{R}^{2}=0,58^{* *}\right)$ ], compacted [B (FMT $701 \mathrm{y}=1,23+1,76 \mathrm{x}+0,66 \mathrm{x}^{2} \mathrm{R}^{2}=0,90 * *$; FMT $705 \mathrm{y}=0,02+0,03 \mathrm{x} \mathrm{R}^{2}=0,69^{* *}$; FMT $707 \mathrm{y}=0,70-0,97 \mathrm{x}+0,36 \mathrm{x}^{2} \mathrm{R}^{2}=0,99^{* *} ;$ FMX 966 LL $\mathrm{y}=-1,71+2,50 \mathrm{x}$ $-0,86 \mathrm{x}^{2} \mathrm{R}^{2}=0,99 * *$; FMX 951 LL $\left.\mathrm{y}=0,68-0,91 \mathrm{x}+0,33 \mathrm{x}^{2} \mathrm{R}^{2}=0,99^{* *}\right)$ ] and lower [C (FMT $701 \mathrm{y}=0,04+0,02 \mathrm{x}$ $\mathrm{R}^{2}=0,78^{*}$; FMT $705 \mathrm{y}=0,07 \mathrm{~ns}$; FMT $707 \mathrm{y}=-0,29+0,53 \mathrm{x}-0,19 \mathrm{x}^{2} \mathrm{R}^{2}=0,72^{* *}$; FMX 966 LL $\mathrm{y}=0,06 \mathrm{~ns}$; FMX 951 LL $\left.\left.y=0,32-0,39 x+0,15 x^{2} R^{2}=0,85^{* *}\right)\right]$ depending on the resistance to penetration in the compacted layer. ** and * significant at $1 \%$ and $5 \%$ respectively. ns: not significant.
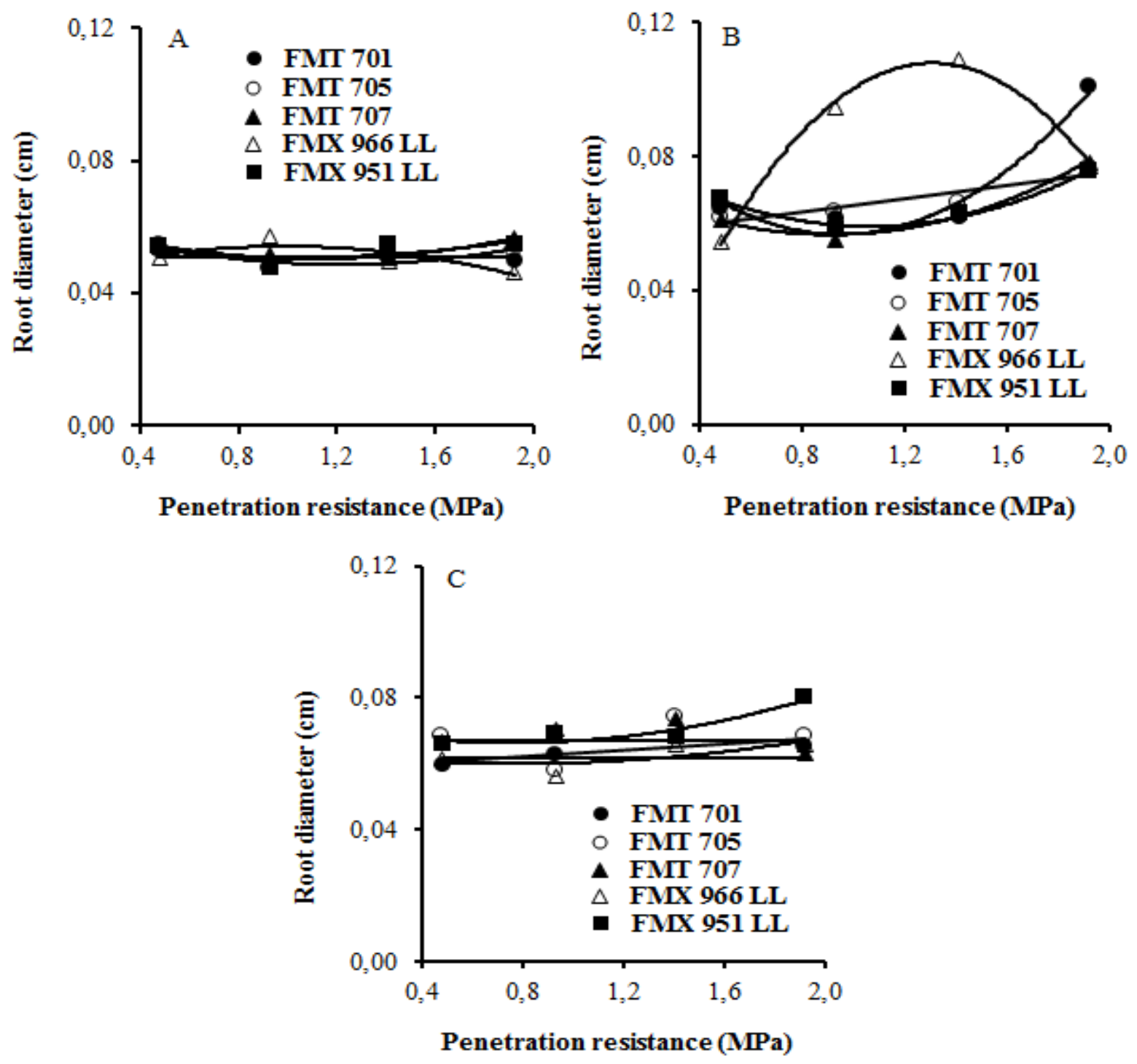

Source: Elaboration of the authors.

\section{Discussion}

Considering the duration of the experiment, we were not expecting to observe an effect of soil compaction on the growth of the shoots as observed for the cultivars FMT 701 and FMX 951
LL. Rosolem, et al. (1994) argued that in the case of cultivation in pots under controlled conditions, similar to this experiment, the increased resistance to penetration in the top layer might not be a limiting factor to the growth of the canopy, because 
the supply of water and nutrients in the soil volume above the compacted layer is relatively high. However, our observation of an increase in growth with soil resistance is not unprecedented, as this has been previously reported in soybean and corn (BORGES et al., 1988; GEDIGA, 1991). According to these reports, this type of result is attributable to better root-soil contact at slightly high resistance values, as well as an increased availability of water, resulting in the increased absorption of both water and nutrients.

Cultivar FMT 707 showed reduced shoot dry matter by approximately $38 \%$ after 23 days of cultivation in pots, with a penetration resistance of $1.92 \mathrm{MPa}$ in the middle layer, compared with uncompacted soil. Silva and Rosolem (2001) reported that sorghum yield was decreased by over $40 \%$ after 38 days of growth at a soil resistance of approximately 1.22 $\mathrm{MPa}$. Foloni, Calonego and Lima (2003) observed a 20\% yield loss in 2 maize cultivars. In these experiments, high water and nutrient availability was always maintained. In an experiment using cotton, Silva, Maia and Bianchini (2006) showed that dry matter production was affected by increased subsurface compaction, which was attributable to a replacement of surface water supply by subsurface irrigation. This would alter the availability of water, so that the increased soil density of $1.0-1.5 \mathrm{Mg} \cdot \mathrm{m}^{-3}$ reduced water consumption by $52 \%$. Thus, small root growth implies low capacity of the plant to obtain the resources necessary for growth, resulting in low productivity.

In this study, the FMT 701 and FMX 951 LL cultivars showed a significant increase in tolerance to compaction, whereas the FMT 707 cultivar showed a high sensitivity to compaction.

With the exception of cultivar FMT 705, the results of root dry matter production confirms the results obtained by Gemtos and Lellis (1997), who observed a similar reduction in cotton cultivars. The FMT 705 cultivar showed no loss in the production of roots, which was similar to the published results on the cultivation of cotton (ROSOLEM et al., 1998), corn (FOLONI; CALONEGO; LIMA, 2003), and soybean (FOLONI; LIMA; BULL, 2006), with no effect on the total yield after an increase in soil penetration resistance in the compacted layers located below $15-\mathrm{cm}$ depth. In all the experiments cited, impairment in the root growth in depth was observed, but the dry mass of roots was maintained. This result may be attributed to the root length density in the upper layer being higher with increasing resistance to penetration, which was due to an increased emission of lateral roots in the surface layer. However, the root length density in the upper layer in our experiment did not have the same development at all levels of compression. Cultivar FMT 705 showed an increase in dry matter and maintained the root length density, and was thus, identified as the least sensitive cultivar to compaction.

In terms of the $\mathrm{Q}_{1 / 2}$ ratio of the cultivars or the PR value in which the root length was reduced by $50 \%$, FMT 701 was the most tolerant cultivar to compaction $\left(\mathrm{Q}_{1 / 2}=1.06 \mathrm{MPa}\right)$, whereas FMT 705 was most sensitive to compaction $\left(\mathrm{Q}_{1 / 2}=0.92\right.$ $\mathrm{MPa}$ ). The $\mathrm{Q}_{1 / 2}$ values of the cultivars were close to the values obtained for other crops commonly used in crop rotation and succession, such as soybeans, with $\mathrm{Q}_{1 / 2}$ of $1.22 \mathrm{MPa}$ (FOLONI; LIMA; BULL, 2006) and 0.69 MPa (ROSOLEM et al., 2004); maize, with $0.75 \mathrm{MPa}$ (FOLONI CALONEGO; LIMA, 2003) and 1.30 MPa (DEXTER, 1987); and sunflower, with 0.86 MPa (ROSOLEM; FOLONI; TIRITAN, 2002). However, the mean $Q_{1 / 2}$ values obtained in our experiment were higher than the 0.72 MPa value reported by Dexter (1987). This shows that the cultivars are susceptible to compaction, but not as sensitive as was considered previously.

Even though cotton root growth was observed in the lower layer of the vessel at all compression levels, from a PR of $1.41 \mathrm{MPa}$, the root system of all cultivars was drastically impaired, with the highest damage to the cultivar FMT 707. These results are consistent with those in the study by 
Taylor, Roberson and Parker Junior (1966), who showed that a resistance of $2 \mathrm{MPa}$ is an impediment to cotton root growth.

The root diameter of the cultivars increased when the penetration resistance increased from 0.48 to $1.92 \mathrm{MPa}$, although this was low in the cultivar FMX 951 LL. These results are in agreement with the data presented by Merotto Junior and Mundstock (1999), as well as with the hypothesis of Russell and Goss (1974) that mechanical soil resistance typically causes increased root diameter within the compacted layer. Silva and Rosolem (2002) argued that thick roots have high ability to grow in high-resistance soil layers, because these roots exert high pressure during growth. According to Henderson (1989), this is relevant in macroporedeficient soils, in which the roots deforming the soil are more important than exploring soil fissures. This was clearly seen with the cultivar FMT 701 $\left(Q_{1 / 2}=1.06\right)$. Our results also confirm the findings of Materechera et al. (1992), who showed that the average root diameter of the cotton plants increased as the root growth in the compacted soil layer was reduced. Glinski and Lipiec (1990) observed an increase in the average root diameter in compacted soil for barley, peas, and maize, and this effect is due to the high extension of the cortex, in which the cells were short in the longitudinal direction and large in the transversal direction, whereas the cell volume remained unchanged.

\section{Conclusions}

1. Cotton cultivars showed minimal variability in sensitivity to soil high penetration resistance. However, in terms of dry matter production, cultivar FMT 707 showed the most sensitive and cultivar FMT 701 showed the highest tolerance to soil compaction.

2. Soil penetration resistance of the order of 1.92 $\mathrm{MPa}$ did not prevent cotton root growth; however, a $50 \%$ growth loss was observed at a penetration resistance range of $0.92-1.06 \mathrm{MPa}$.

\section{References}

BORGES, E. N.; NOVAIS, R. F.; REGAZZI, A. J.; FERNANDES, B.; BARROS, N. F. Respostas de variedades de soja à compactação de camadas de solo. Revista Ceres, Viçosa, v. 35, n. 2, p. 553-568, 1988.

BUSSCHER, W. J.; FREDERICK, J. R.; BAUER, P. J. Timing effects of deep tillage on penetration resistance and wheat and soybean yield. Soil Science Society America Journal, Madison, v. 64, n. 3, p. 999-1003, 2000.

CALONEGO, J. C.; ROSOLEM, C. A. Least limiting water range in soil under crop rotations and chiseling. Revista Brasileira de Ciência do Solo, Viçosa, MG, v. 35, n. 3, p. 759-771, 2011.

COELHO, M. B.; MATEOS, L.; VILLALOBOS, F. J. Influence of a compacted loam subsoil layer on growth and yield of irrigated cotton in Southern Spain. Soil \& Tillage Research, Amsterdam, v. 57, n. 2, p. 129-142, 2000.

COUTO, L.; SANS, L. M. A. Características fisicohídricas e disponibilidade de água no solo. Sete Lagoas: Centro Nacional de Pesquisa de Milho e Sorgo, 2002. 8 p. (Circular técnica, 21).

DEXTER, A. R. Mechanics of root growth. Plant and Soil, The Hague, v. 98, n. 3, p. 303-312, 1987.

EMPRESA BRASILEIRA DE PESQUISA AGROPECUÁRIA - EMBRAPA. Sistema brasileiro de classificação de solos. Rio de Janeiro: Centro Nacional de Pesquisa de Solos, 1999. 412 p.

FOLONI, J. S. S.; LIMA, S. L.; BULL, L. T. Crescimento aéreo e radicular da soja e de plantas de cobertura em camadas de solo compactado. Revista Brasileira de Ciência do Solo, Viçosa, MG, v. 30, n. 1, p. 48-57, 2006.

FOLONI, J. S. S.; CALONEGO, J. C.; LIMA, S. L. Efeito da compactação do solo no desenvolvimento aéreo e radicular de cultivares de milho. Pesquisa Agropecuária Brasileira, Brasília, v. 38, n. 8, p. 947-953, 2003.

FREDERICK, J. R.; BAUER, P. J.; BUSSCHER, W. J.; MCCUTCHEON, G. S. Tillage management for double cropped soybean grown using narrow and wide rowwidth culture. Crop Science, Madison, v. 38, n. 3, p. 755 762, 1998.

GEDIGA, K. Influence of subsoil compaction on the uptake of $45 \mathrm{Ca}$ from the soil profile and on maize yield. Soil \& Tillage Research, Amsterdam, v. 19, n. 3, p. 351355, 1991. 
GEMTOS, T. A.; LELLIS, T. Effects of soil compaction, water and organic matter contents on emergence and initial plant growth of cotton and sugar beet. Journal Agricultural Engineering Research, Amsterdam, v. 66, n. 2, p. 121-134. 1997.

GLINSKI, J.; LIPIEC, J. Soil physical conditions and plant roots. Boca Raton: CRC Press, 1990. 250 p.

HAMZA, M. A.; ANDERSON, W. K. Soil compaction in cropping systems: a review of the nature, causes and possible solutions. Soil \& Tillage Res., Amsterdam, v. 82, n. 2, p. 121-145, 2005.

HENDERSON, C. W. L. Using a penetrometer to predict the effects of soil compaction on the growth and yield of wheat on uniform, sandy soils. Australian Journal of Agricultural Research, Collingwood, v. 40, n. 3, p. 497508, 1989.

KASPERBAUER, M. J.; BUSSCHER, W. J. Genotypic differences in cotton root penetration of compacted subsoil layer. Crop Science, Madison, v. 31, n. 5, p. 13761378, 1991.

MATERECHERA, S. A.; ALSTON, A. M.; KIRBY, J. M.; DEXTER, A. R. Influence of root diameter on the penetration of seminal roots into a compacted subsoil. Plant and Soil, The Hague, v. 144, n. 2, p. 297-303, 1992.

MEROTTO JUNIOR, A.; MUNDSTOCK, C. M. Wheat root growth as affected by soil strength. Revista Brasileira de Ciência do Solo, Viçosa, MG, v. 23, n. 1, p. 197-202, 1999.

MÜLleR, M. M. L.; CECCON, G.; ROSOLEM, C. A. Influência da compactação do solo em subsuperfície sobre o crescimento aéreo e radicular de plantas de adubação verde de inverno. Revista Brasileira de Ciência do Solo, Viçosa, MG, v. 25, n. 3, p. 531-538, 2001.

RAIJ, B. van; QUAGGIO, J. A. Métodos de análise de solos para fins de fertilidade. Campinas: Instituto Agronômico, 1983. 31 p.

ROSOLEM, C. A.; FOLONI, J. S. S.; TIRITAN, C. S. Root growth and nutrient accumulation in cover crops as affected by soil compaction. Soil \& Tillage Research., Amsterdam, v. 65, n. 1, p. 109-115, 2002.
ROSOLEM, C.A.;ALMEIDA,A.C.S.; SACRAMENTO, L. V. S. Sistema radicular e nutrição da soja em função da compactação do solo. Bragantia, Campinas, v. 53 , n. 1, p. 259-266, 1994.

ROSOLEM, C. A.; SCHIOCHET, M. A.; SOUZA, L. S.; WHITAKER, J. P. T. Root growth and cotton nutrition as affected by liming and soil compaction. Communications in Soil Science and Plant Analysis, New York, v. 29, n. 1-2, p. 169-177, 1998.

RUSSEL, R. S.; GOSS, M. J. Physical aspects of soil fertility: the response of roots the mechanical impedance. Netherlands Journal of Agricultural Science, Wageningen, v. 22, n. 3, p. 305-318, 1974.

SILVA, G. J.; MAIA, J. C. S.; BIANCHINI, A. Crescimento de parte aérea de plantas cultivadas em vaso, submetidas à irrigação subsuperficial e a diferentes graus de compactação de um Latossolo vermelho-escuro distrófico. Revista Brasileira de Ciência do Solo, Viçosa, MG, v. 30, n. 1, p. 31-40, 2006.

SILVA, R. H.; ROSOLEM, C. A. Crescimento radicular de espécies utilizadas como cobertura decorrente da compactação do solo. Revista Brasileira de Ciência do Solo, Viçosa, MG, v. 25, n. 1, p. 253-260, 2001.

Crescimento radicular de soja em razão da sucessão de cultivos e da compactação do solo. Revista Brasileira de Ciência do Solo, Viçosa, MG, v. 37, n. 6, p. 855-860, 2002.

SOANE, B. D.; VAN OUWERKERK, C. Soil compaction in crop production. Amsterdam: Elsevier, 1994. 342 p.

TAYLOR, H. M.; GARDNER, H. Penetration of cotton seedling taproots as influenced by bulk density, moisture content, and strength. Soil Science, Phyladelphia, v. 96, n. 2 p. 153-156, 1963.

TAYLOR, H. M.; ROBERSON, G. M.; PARKER JUNIOR, J. J. Soil strength-root penetration relations to medium to coarsetextured soil materials. Soil Science, Philadelphia, v. 102, n. 1, p. 18-22, 1966. 
